\title{
Constructed Wetland Systems as a Methodology for the Treatment of Wastewater in Bucaramanga Industrial Park
}

\author{
Chukwunonye Ezeah1, Carlos Alberto Ríos Reyes², Jairo Fernando Contreras Gutiérrez² \\ ${ }^{1}$ Faculty of Sciences and Engineering, University of Wolverhampton, Wolverhampton, UK \\ ${ }^{2}$ Universidad Industrial de Santander, Bucaramanga, Colombia \\ Email: C.Ezeah2@wlv.ac.uk
}

Received 13 March 2015; accepted 17 April 2015; published 21 April 2015

Copyright (c) 2015 by authors and Scientific Research Publishing Inc.

This work is licensed under the Creative Commons Attribution International License (CC BY). http://creativecommons.org/licenses/by/4.0/

(c) (i) Open Access

\begin{abstract}
Effluent discharges from municipal, industrial, and agricultural activities constitute major sources of pollution on land and water bodies. During the 1990s, large-scale application of Constructed Wetlands (CWs) as a remediation option drew much attention globally from the public and green groups alike. The most common application of CWs is for flow management in river system and little is documented on using CWs for treating polluted river water. This article goes beyond constructed wetlands as a stand-alone methodology to propose an integrated remediation system incorporating constructed wetlands in Bucaramanga Industrial Park S.A., Santander (Colombia), which will form part of an innovation park. In addition to pollution abatement, the project is projected to provide other environmental benefits to the entire Oro River Sub-basin. Other benefits of the project include mitigation of environmental impacts, improvement in water quality, landscape amenity, as well as tourism and recreational benefits.
\end{abstract}

\section{Keywords}

Water Pollution, Constructed Wetlands, Wastewater, Integrated Remediation System, Tourism and Recreation

\section{Introduction}

The application of constructed wetlands (CWs) for wastewater treatment has gained significant acceptability in recent times particularly in emerging economies as a result of their versatility, economic and environmental merits such as the provision of esthetic and recreational opportunities, wildlife habitats, walking routes, land pre- 
servation, erosion control, and tourism. If CWs' application were to be more sustainable in the future, there would be a need to ensure greater economic and social viability as well as reduction of negative environmental impacts. The technology of CWs is generally regarded as low-cost, easily operated and a viable alternative to conventional wastewater treatment systems. CWs are unique as compared with other wastewater treatment options because they use natural vegetation, microorganism and soil as key elements in the treatment process. Constructed wetlands have been recognized as providing other benefits aside from drinking water supply purification such as wildlife conservation, fish and invertebrates breeding, erosion control, gene pools and diversity, energy generation, education and training, recreation, and reclamation [1]-[6]. Since CWs are increasingly becoming important as an alternative method of wastewater treatment, it has become even more imperative to further understand how they work so as to better design improvements and develop new systems for monitoring ecological recovery.

Companies operating along the Bucaramanga Industrial Park S.A., Santander (Colombia) generate different types of pollutants which are usually discharged into the Oro River, leading to extensive contamination particularly by heavy metals. Heavy metals can be harmful to human health and the environment at certain concentrations, usually identified as thresholds by environmental regulations. The main purpose of this research is to propose an integrated system of constructed wetland as an alternative for the conservation and rehabilitation of water within the Bucaramanga Industrial Park S.A, as a means of improving water quality and landscape amenity, providing tourism and recreational opportunities, creating habitat for fauna and flora, harvesting storm water, augmenting storage capacities of underground aquifers, improving flood management systems, enhancing community education, and bringing about more positive public attitude towards the environment in general.

\section{Overview of the Case Study Area}

The Oro River Sub-basin forms part of the hydrographic zone of the Magdalena Middle Valley and is located within the Lebrija River Basin (Santander). The municipalities of Bucaramanga, Floridablanca, Girón, Piedecuesta and Tona are all located within the Oro River Basin. The area is a major tourist destination for both local and international visitors. The population of the basins makes up over $40 \%$ of the total population of Santander. The Bucaramanga Industrial Park S.A. is located along the valley between the Palonegro High and northern Bucaramanga (Figure 1), which is a major development area in close proximity to Barrancabermeja and Venezuelan borders. The area is home to a number of companies involved in the oil industry as well as those involved in chemicals, auto parts and food manufacturing. In addition, the area also receives effluent discharges from nearly a million people who live in Bucaramanga city and its surroundings.

\section{Literature Review}

Natural wetlands are considered the most biologically diverse of all ecosystems and their major functions include holding and recycling nutrients, providing wildlife habitats, stabilizing shorelands, controlling and buffering natural floods, recharging groundwater as well as providing treatment for pollutants in water [7]. CWs are artificial systems that mimic the functions of natural wetlands in a specific environment and can be controlled and manipulated to achieve desired results. CWs provide a low-cost alternative for treatment for wastewater while achieving significant improvements in water quality through a variety of physical, chemical and biological processes. The Chinese and Egyptians have used natural wetlands for thousands of years for water purification. However, the first artificial wetland was not used until 1904 (in Australia). To date, the most common application of CWs is for flow management in river system [8], and little is documented on using CWs for treating polluted river water [9]-[12].

Typical configurations of CWs are detailed by [13] and [14], as shown in Figure 2. CWs are classified according to their mode of operation as horizontal flow system (HFS) and vertical flow system (VFS). In the HFS (Figure 2(a)) wastewater is fed at the inlet and flows horizontally through the bed to the outlet. HFS has two general types: sub-surface flow (SSF) and surface flow (SF). CWs can also be classified according to the life form of dominating vegetation and according to the flow pattern. The SSF systems (Figure 2(b)) move effluent through a gravel or sandy medium on which plants are rooted. The effluent may move either horizontally, parallel to the surface, or vertically, from the planted layer down through the substrate and out. They are less hospitable to mosquitoes, whose populations can be a problem in CWs. These systems have the advantage of requiring less land area for water treatment, but are not generally as suitable for wildlife habitat as are SF systems (Figure 2(c)), which move effluent above the soil in a planted marsh or swamp, and thus can be supported by a wider 

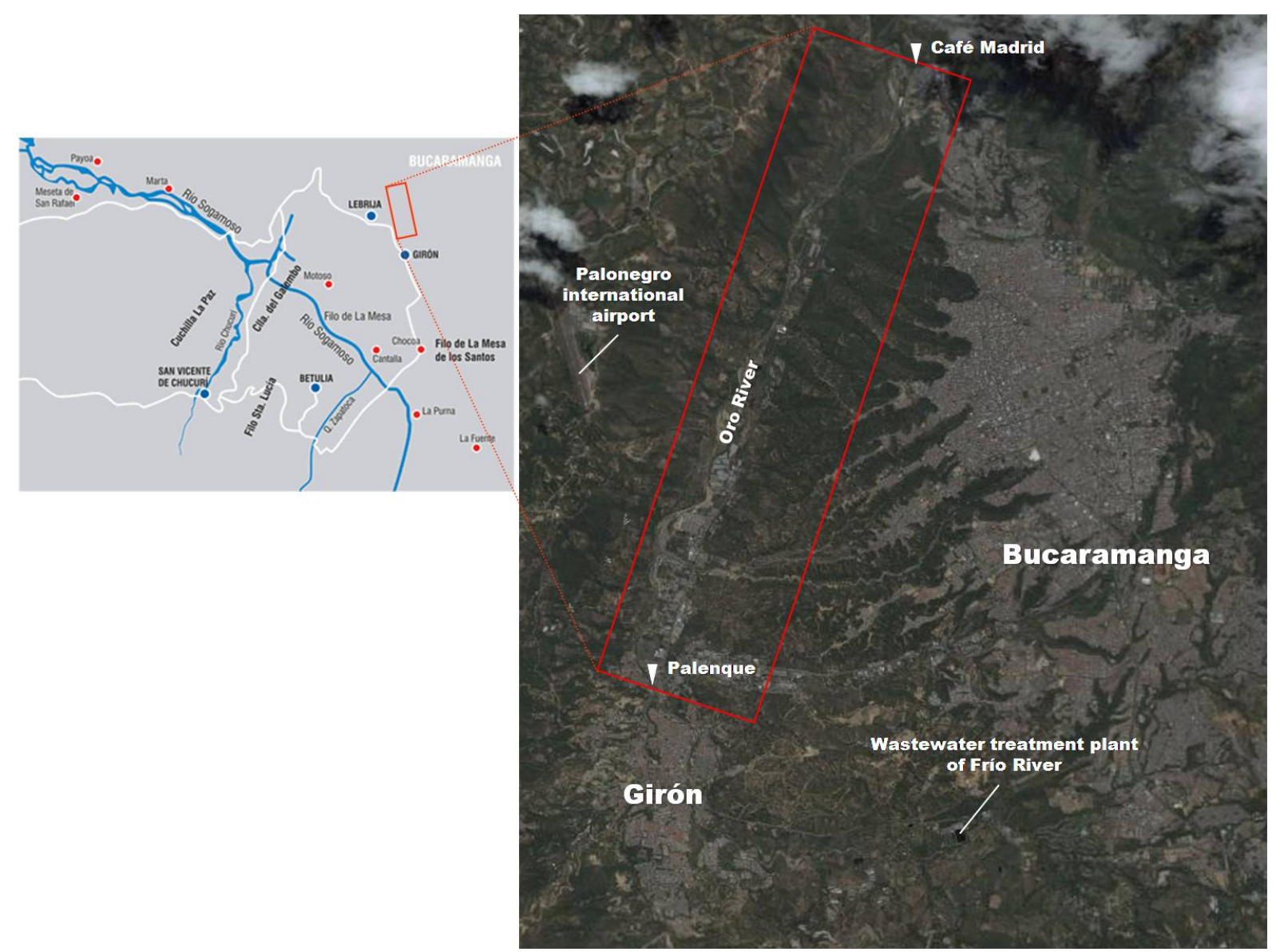

Figure 1. Location of Bucaramanga Industrial Park S.A.

variety of soil types including bay mud and other silty clays.

If planned and maintained properly, CWs can provide wastewater treatment and also promote water reuse, wildlife habitat, and public use benefits [15] [16]. Potentially harmful environmental impacts, such as the alteration of natural hydrology, introduction of invasive species and the disruption of natural plant and animal communities can be avoided by following proper planning, design, construction and operating techniques. The design and planning of the $\mathrm{CW}$ treatment system should be carried out taking into account several aspects. According to USEPA [16], the following considerations can help ensure a successful project: 1) CW treatment system, as a rule, on uplands and outside floodplains in order to avoid damage to natural wetlands and other aquatic resources, unless pre-treated effluent can be used to restore degraded systems; 2) Consider the role of treatment wetlands within the watershed (e.g., potential water quality impacts, surrounding land uses and relation to local wildlife corridors); 3) Closely examine site-specific factors, such as soil suitability, hydrology, vegetation, and presence of endangered species or critical habitat, when determining an appropriate location for the project in order to avoid unintended consequences, such as bioaccumulation or destruction of critical habitat; 4) Use water control measures that will allow easy response to changes in water quantity, quality, depth and flow; 5) Create and follow a long-term management plan that includes regular inspections, monitoring and maintenance. While CWs are primarily treatment systems, they provide intangible benefits by increasing the aesthetics of the site and enhancing the landscape [17]. Visually, they are unusually rich environments, which by introducing the element of water to the landscape, as much as natural wetlands, add diversity to the landscape. CWs can be developed into healthy ecosystems that are productive, diverse and resilient, with a significant biomass of plants and microorganisms, which take up nutrients and provide habitat and food for animals, as well as plant and microbial species that promote materials transfer and decomposition of organic material. This technology will be productive, diverse and resilient so they can continue to perform their pollutant removal function effectively, and healthy ecosystems, once established in CWs, will maintain themselves indefinitely through growth and reproduction of 


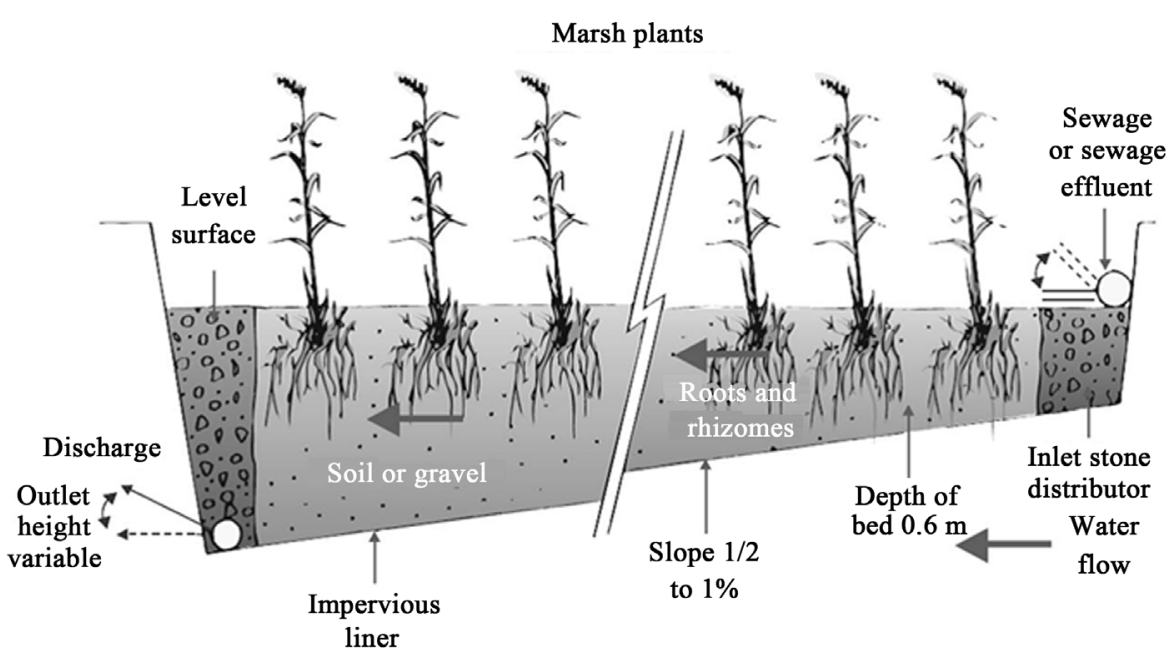

(a)

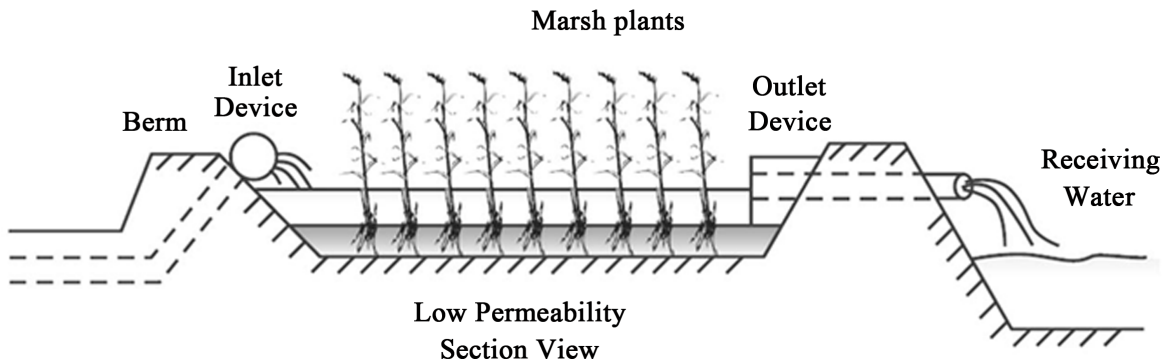

(b)

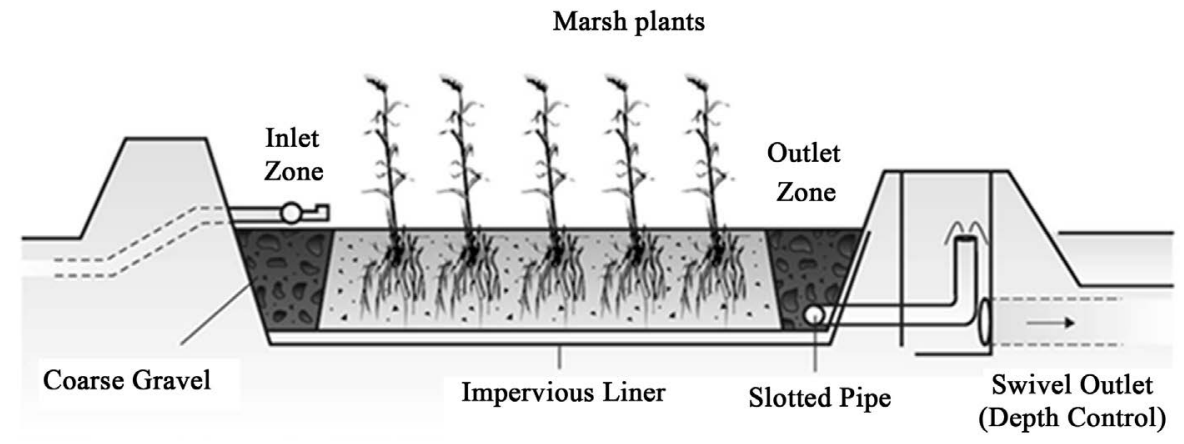

(c)

Figure 2. Typical configurations of (a) horizontal-flow wetland; (b) sub-surface flow wetland; (c) surface flow wetland systems (modified from Cooper, Job, Green and Shutes [13], and Kadlec and Knight [14]).

all species of plants and animals with minimal on-going maintenance [18]. Apart from environmental benefits, this project is aimed at enhancing the tourism potential of the case study area.

\section{Research Methodology}

Figure 3 is a flowchart outlining the project development process. Table 1 is an outline of design parameter on which the CWs are constructed based on [19]. Figure 4 is a layout of the site comprising of a small lagoon $\left(\mathrm{CW}_{1}\right)$ which connects to the Oro River at its downstream end. This lagoon will be further connected to a number of smaller artificial lagoons upstream. A number of small man-made creeks will also be created. The network of lagoons which will comprise the main body of the wetland will be separated from the causeways. Within each of the causeways, 6inch diameter pipes will be used to interconnect the lagoons (Figure 2(b)). The 


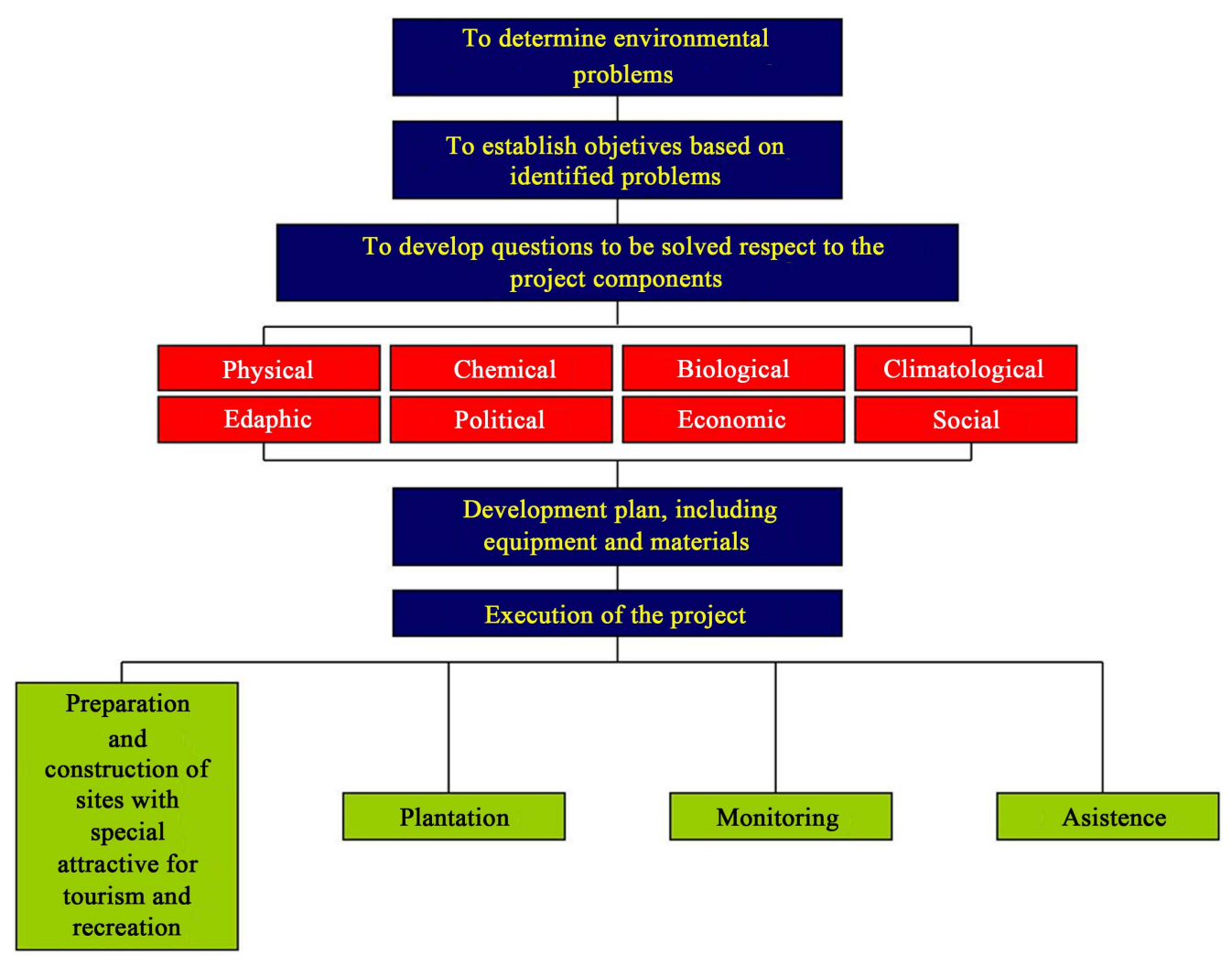

Figure 3. Outline of project development process.

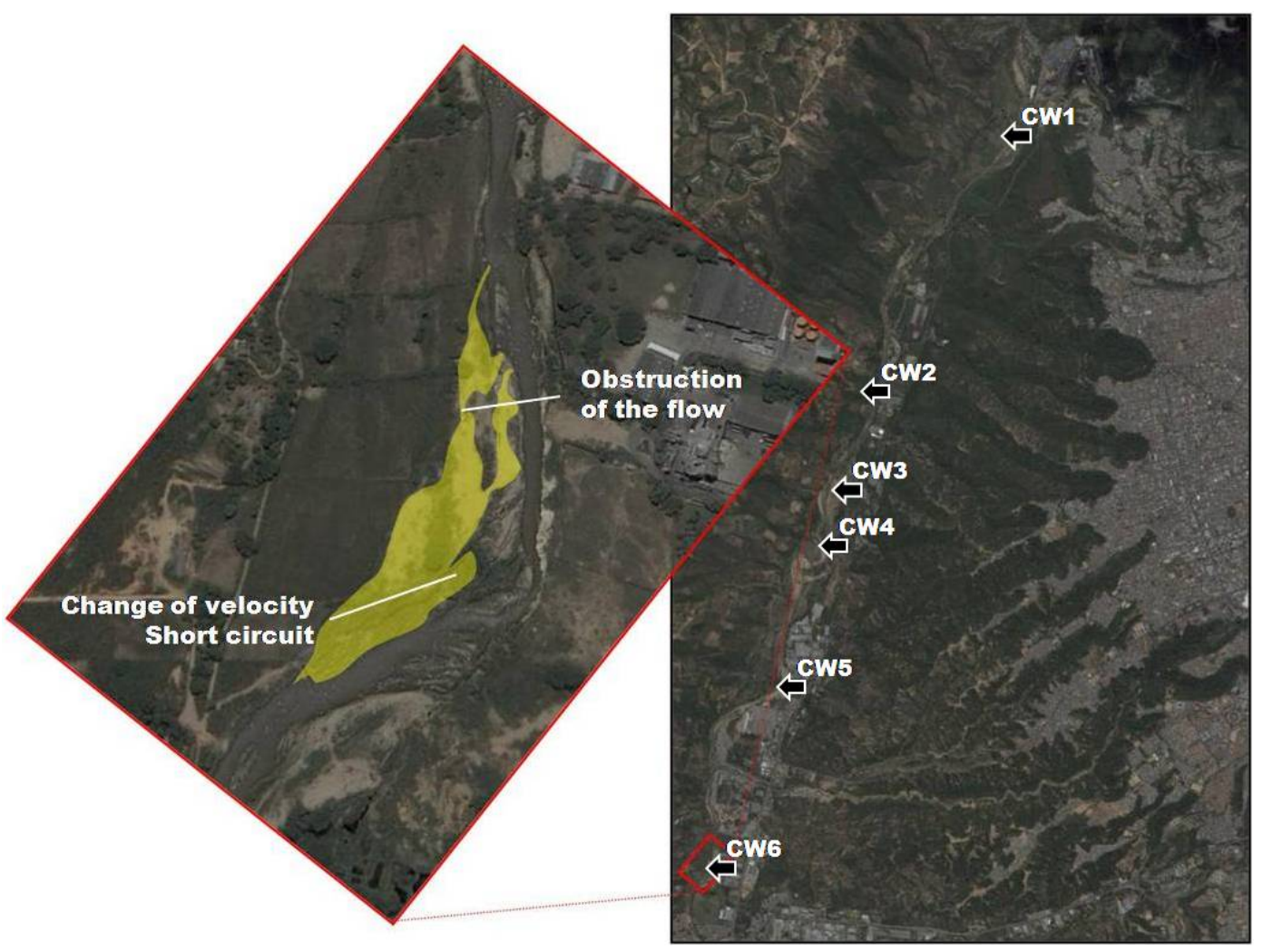

Figure 4. Site map indicating location of $\mathrm{CW}_{1-6}$ on downstream Oro River. 
Table 1. Recommendations on the design and operation of CWs for wastewater treatment.

\begin{tabular}{ccc}
\hline & Design criteria & \\
Parameter & FWS CWs & SSF CWs \\
\cline { 2 - 3 } Bed size $\left(\mathrm{m}^{2}\right)$ & Larger if available & $<2500$ \\
Length to width ratio & $3: 1-5: 1$ & $0.4-1.6$ \\
Water depth (m) & $0.3-0.5$ & $0.5-1$ \\
Hydraulic slope (\%) & $<0.5$ & $<0.5$ \\
Hydraulic loading rate (m/day) & $<0.1$ & $2-5$ \\
Hydraulic retention time (day) & $5-30$ & Natural media and industrial by-product preferred, porosity $0.3-0.5$, \\
Media & particle size $<20$ mm $(50-200$ mm for the inflow and outflow) \\
Vegetation & Native species preferred, plant density $80 \%$ coverage \\
\hline
\end{tabular}

Based on Wu, Zhang, Ngo, Guo, Hub, Liang, Fan and Liu [19].

larger downstream lagoon would be connected to the river via 12 inch pipe (Figure 2(c)). Parts of the sites on the banks of the river will be redeveloped into wetlands made up of interconnecting rectangular shaped ponds (Figure 4 and Figure 5).

Table 2 is an outline of commonly used materials for $\mathrm{CW}$ construction to enhance sustainability the project will prioritize the use of local materials as much as possible.

\section{Discussion}

\subsection{Environmental Impacts}

Environmental degradation arising from anthropogenic activities are increasingly evident in many regions and ecosystems of developing countries, in wetlands, croplands where cattle are fed on crop residues, in grasslands subsequent to seasonal harvest [35]. According to the UNRISD [36], environmental degradation, including depletion of renewable and non-renewable resources and pollution of air, water and soils, can be a significant source of stress upon societies. It can act on social integration indirectly, through the constraints that it puts on productive activities, and it can also have other indirect social impacts. It is therefore true that environmental degradation can most probably be understood within the context of the society that the environment supports. Changing patterns of social integration affect the ways in which natural resources are utilized by society, the value ascribed to nature, and the importance attached to environmental conservation and rehabilitation. In Colombia, environmental degradation is often as a result of the dynamic interplay of socio-economic, institutional and technological activities. It is driven by such factors as, population growth [37] and economic development [38]; with uncontrolled growth of urbanization and industrialization, expansion and massive intensification of agriculture and the destruction of forests. Water shortages, soil exhaustion and erosion, deforestation, air and water pollution affects many areas. One of the primary causes of environmental degradation in the Oro River Sub-basin has been attributed to the rapid population growth within the basin and adjourning areas. The twin problems of uncontrolled population growth rate and consequent environmental degradation have posed significant challenge to sustainable development. Furthermore, it has also been noted that presence or absence of natural resources can facilitate or retard the process of socio-economic development, ultimately leading to irreversible changes to the natural environment. This changing consumption pattern is reported to be primarily responsible for rising demand for energy in the region. Ultimately, the consequences of these dynamic changes are such intractable problems as air pollution, global warming, climate change, water scarcity, water pollution and land contamination. Environmental problems within the Oro River Sub-basin such as floods, erosion, landslides, flows and avalanches, poor agricultural practices and unsustainable resource utilization have led to significant transformation of the area's natural environment (Figure 6(a)). Urgent legislative intervention is required so as to avoid continued human settlement and other developments around the areas noted for high threat of landslides. In addition to this other causes of environmental degradation need to be addressed urgently [39]. 


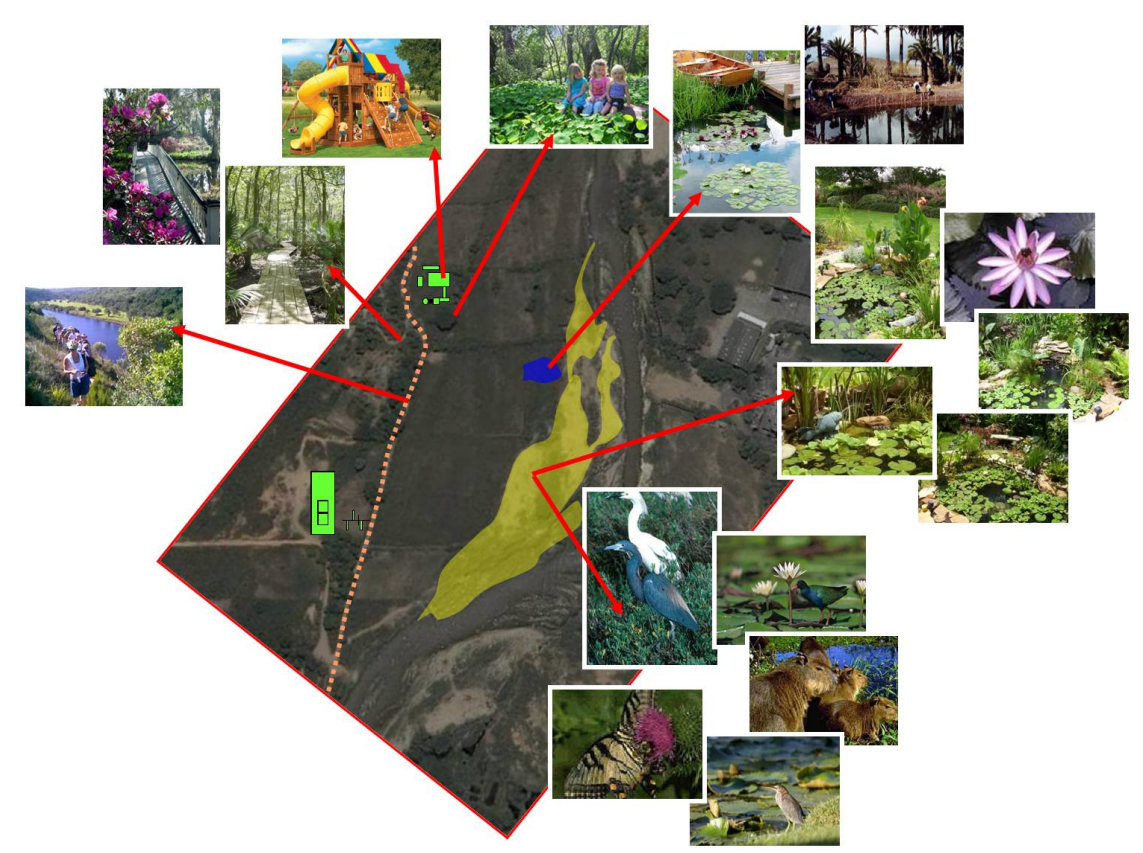

Figure 5. An indicative map of the site showing environmental aspects.
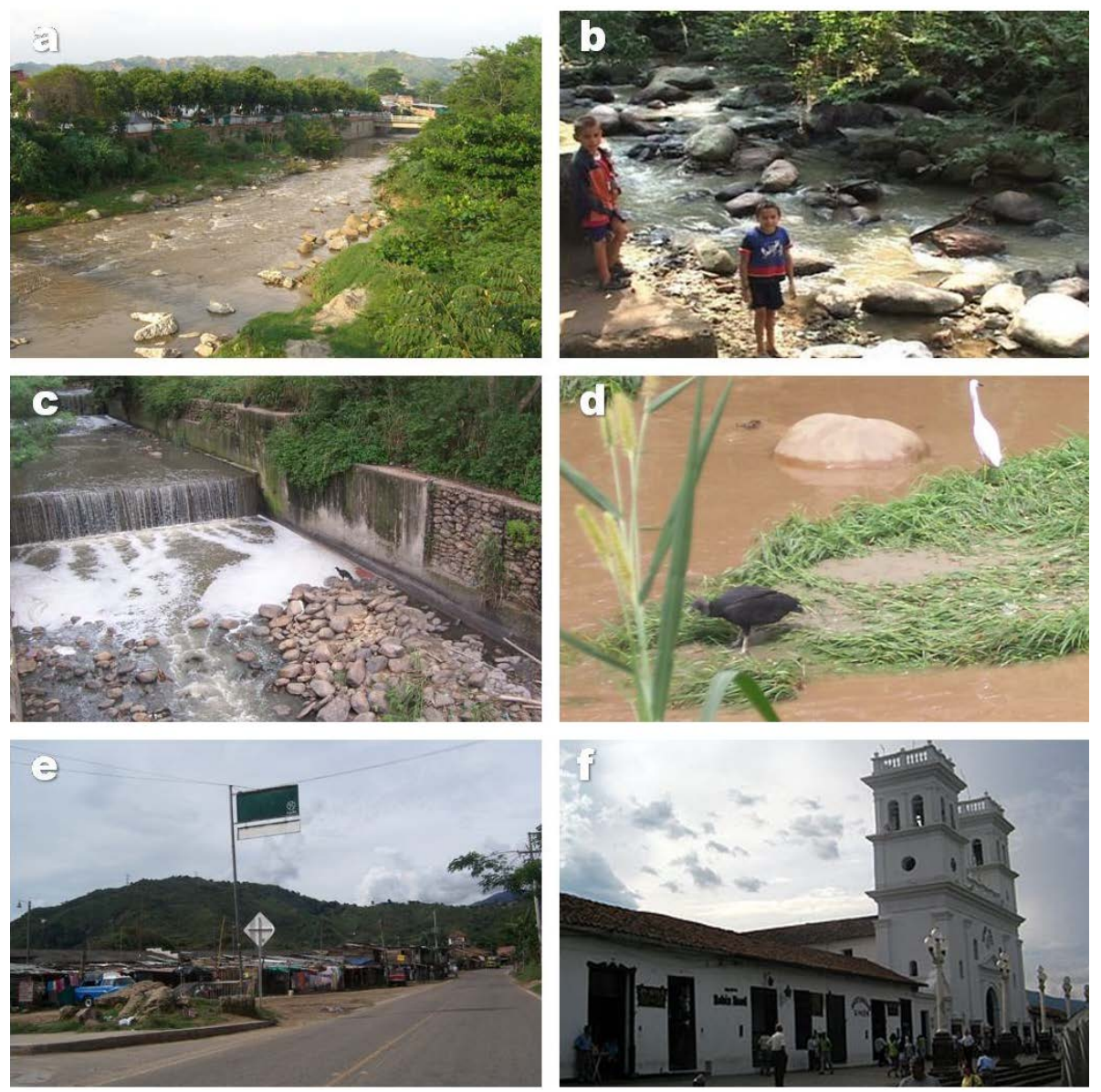

Figure 6. Problems associated with the pollution of the Oro River along the Bucaramanga Industrial Park S.A. 
Table 2. Substrates commonly selected for CW wastewater treatment.

\begin{tabular}{|c|c|}
\hline Type of substrates & Source \\
\hline \multicolumn{2}{|l|}{ Natural material } \\
\hline Sand & Saeed and Sun [20] \\
\hline Gravel & Calheiros, Rangel and Castro [21] \\
\hline Clay & Calheiros, Rangel and Castro [21] \\
\hline Calcite & Ann, Reddy and Delfino [22] \\
\hline Marble & Arias, Del Bubba and Brix [23] \\
\hline Vermiculite & Arias, Del Bubba and Brix [23] \\
\hline Bentonite & $\mathrm{Xu}, \mathrm{Xu}, \mathrm{Wu}$ and Muhammad [24] \\
\hline Dolomite & Ann, Reddy and Delfino [22] \\
\hline Limestone & Tao and Wang [25] \\
\hline Shell & Seo, Cho, Lee and Heo [26] \\
\hline Shale & Saeed and Sun $[20]$ \\
\hline Peat & Saeed and Sun $[20]$ \\
\hline Wollastonite & Brooks, Rozenwald, Geohring, Lion and Steenhuis [27] \\
\hline Maerl & Saeed and Sun $[20]$ \\
\hline Zeolite & $\begin{array}{l}\text { Bruch, Fritsche, Bänninger, Alewella, Sendelov, } \\
\text { Hürlimann, Hasselbach and Alewell [28] }\end{array}$ \\
\hline \multicolumn{2}{|l|}{ Industrial by-product } \\
\hline Slag & Cui, Ouyang, Lou, Yang, Chen, Zhu and Luo [29] \\
\hline Fly ash & $\mathrm{Xu}, \mathrm{Xu}, \mathrm{Wu}$ and Muhammad [24] \\
\hline Coal cinder & Ren, Zhang, Liu and Wang [30] \\
\hline Alum sludge & Babatunde, Zhao and Zhao [31] \\
\hline Hollow brick crumbs & Ren, Zhang, Liu and Wang [30] \\
\hline Moleanos limestone & Mateus, Vaz and Pinho [32] \\
\hline Wollastonite tailings & Hill, Payne, Rogers and Kown [33] \\
\hline Oil palm shell & Chong, Chia and Ahmad [34] \\
\hline \multicolumn{2}{|l|}{ Artificial products } \\
\hline Activated carbon & Ren, Zhang, Liu and Wang [30] \\
\hline Light weight aggregates & Saeed and Sun [20] \\
\hline Compost & Saeed and Sun [20] \\
\hline
\end{tabular}

Adapted from Wu, Zhang, Ngo, Guo, Hub, Liang, Fan and Liu [19].

\subsection{Impact on Water Quality}

Water is an invaluable commodity in nature and can be a limiting resource to living beings. Water quality is influenced by both natural and anthropogenic intervention where the former includes local climate, geology, etc. and the later includes the construction of dams and embankments, irrigation practices, indiscriminate disposal of industrial effluents, etc. [40]. Deterioration of water quality can have many negative impacts on aquatic ecosystems [41]. Water quality in rivers can be reduced by high sediment loads that interfere with fish respiration and 
cover spawning areas and can smother bottom-living organisms. Several pollutants have differing effects ranging from inducing catastrophic mortality to chronic illness, in addition to the effects of bio-accumulation through the food chain. Actually, in Colombia acute pollution prevails in many rivers at industrial zones, e.g., the Bucaramanga Industrial Park S.A. The quality of river water is deteriorating because of pollution. The Oro River Sub-basin is used as a sink for industrial wastes from surrounding industrial areas and municipal wastes from the Bucaramanga's metropolitan area (Figure 6(c)), and at the same time it remains as the main source of water supply to the entire region. The main pollution is of organic nature coming from such industries as food, petro chemicals and car parts, which contribute organic matter, biochemical oxygen demand (BOD), suspended solids $(\mathrm{SS})$, phosphorus $(\mathrm{P})$ and nitrogen $(\mathrm{N})$ to the total pollution load. Vehicle repair workshops contribute oils, grease and heavy metals. However, remnants of pollutants pose potential environmental and health hazards, which include heavy metals from leather tanning and metal industries. Therefore, pollutants comprise a broad range of organic and inorganic compounds and their sources are equally diverse and effective interventions are consequently difficult to target. In spite of the organic recovery in the Oro River's tributaries is satisfactory from the standpoint of oxygen demand and the trajectory of these channels acts as a wastewater treatment plant, the water quality found in this area is low. The minimum concentration of faecal coliforms exceeds the permitted parameters. There is a strong concentration of inorganic dissolved solids. High concentrations of nitrogen and phosphorus have affected the generation of plant life. The extent of turbidity reaffirms the status of suspended solids removal by the special status of the channel river subject to extraction of materials. The status of the quality of the streams mainly by the bacteriological condition creates conflicts with everything involving water use that need consumption or direct contact by the human being.

\subsection{Loss of Biodiversity}

The extinction of certain species could lead directly to the loss of fauna and flora in a habitat as occurring in the Bucaramanga Industrial Park S.A. (Figure 6(d)). We need to understand how biodiversity works in order to predict what effect loss of species will have. The major direct causes of biodiversity loss are the fragmentation, degradation or loss of habitats; the over-exploitation of natural resources; pollution; the introduction of non-native (alien) species and climate change. Among the most important underlying causes of biodiversity loss are illfitted policies, undefined lands and resources rights, and the macro-economic context which affects both peoples and ecosystems alike. However, economic growth is considered as the primary driver of the main reason for biodiversity loss-habitat destruction [42]. Economic growth also contributes to the other main causes of biodiversity loss. There is a fundamental conflict between economic growth and biodiversity conservation [43]. In Colombia, the main causes of change in supply of the soils originate in both over-exploitation and under-utilization of land resources, since the current uses do not understand the limitations and potentialities imposed by nature and dynamics. Largely, use conflicts proceed from the increasing transformation of agricultural and forest lands, as well as those appropriate for the integral conservation and recovery of water resources towards farming lands, which promotes biodiversity loss, soil compaction, degradation of strategic ecosystems and less generation of rural employment. Moreover, land under-utilization leads to problems in food supply, social discontent and overuse of other resources within the fragile ecosystems. Forest resources and biodiversity are potential environmental assets; where ecosystems such as tropical rainforest, areas with unique natural beauty, wilderness areas and special vegetation are impacted, species diversity could be impaired.

\subsection{Loss of Landscape Values}

Landscapes change because they are the expression of the dynamic interaction between natural and cultural forces in the environment [44]. Although there is no economic reason which justifies loss of landscape values in the long term, strong pressure on landscapes often leads to severe environmental problems, changes in landscape character, and loss of landscape value [45]. This phenomenon can generate very negative effects on fragile ecosystems. It also significantly reduces the efficiency of the ecological systems. In this case what is at stake is not only the loss of identity values but also the possibility to use the landscape in the production of tourist and recreational goods. The continuous onslaught of pollutants has adversely affected water quality, destroyed the natural landscape and played havoc with the unique ecosystem. Therefore, efforts are required to assure the rehabilitation of the badly-polluted Oro River in the Bucaramanga Industrial Park S.A. It is anticipated that this project would lead to the rehabilitation of affected areas along this river and transformation of degraded areas 
that have lost most of its value (Figure 6(e)) into an attractive one. In addition, the project will promote efficient waste management, sludge removal and treatment, riverside landscaping, flood protection, and development of recreation and tourism facilities. Loss of aesthetics is often a key indicator of adverse environmental impact [46] [47]. A major contributory factor to this situation includes unsustainable agricultural practices such as over-application of inorganic fertilizer and poor manure management together with inadequate treatment and disposal of municipal sewage. Aspects of this project will be used to demonstrate best agricultural practices so as to help drive change in public perception and habits [48].

\subsection{Health Impacts}

The high levels of pollution in the Bucaramanga Industrial Park S.A. directly affect the health of the population living in this area (Figure 6(b)). Consequently, diseases such as diarrhoea and severe respiratory infections have been reported. Air pollution arising from particulate matter from industries has been reported to be higher than acceptable limits. There could therefore be a co relation between reported increased mortality [49] and morbidity [50] in the exposed population by respiratory [50] [51], cardiovascular [52] and central nervous system [53] problems. Acute diarrhoea and Cholera have also been reported to account for $80 \%$ deaths [54] [55]. Treatment with oral rehydration solution has reduced the levels of mortality in children and adult by dehydration, but not morbidity for diarrhoea [56]. As a result of the prevailing contamination in the river, the population is exposed to a permanent health risk. It has been suggested that government should explore options for public-private partnership in combating pollution, offering opportunities in joint investment in the development and financing of sustainable waste management programs, facilities and services [57]. Therefore, a change in thinking with regard to waste management: waste (both liquid and solid) should be considered as a resource rather than unwanted by-product of human activities. Waste management can be viewed not only as a means to protect the environment and human health but also as an opportunity to develop the social wellbeing of the affected community through the creation of new commercial activities and possibly to create new jobs [46] [58].

\subsection{Lack of Opportunities for Tourism and Recreation}

Recently, as a result of its peculiar geomorphologic characteristics, the Oro River basin is becoming an important tourism destination and recreation alternative for its inhabitants (Figure 6(f)). Notwithstanding, investment continues to tilt towards industrial development at the expense of tourism and recreation development. It is envisaged that this project will help in the development of the area's tourism potentials thereby further impacting the entire economy. However, CWs in urban regions may take on human-related values that they lack in nonurban areas, as they provide some contact with nature, and some opportunities for tourism and recreation that are otherwise rare in the urban landscape [59]. Burger [60] presents examples of how tourism/recreation can enhance the conservation of land on a landscape scale, leading to habitat protection and biodiversity preservation.

\section{Economic, Environmental and Social Feasibility}

CWs should be developed in a sustainable way, to be economically, environmentally and socially viable and acceptable to reduce negative environmental impacts. However, several aspects should be considered. Projects as CWs have remarkable effects on economic and social areas, apart from already reported environmental impacts. The creation of CWs can also assist in changing the way people relate amongst themselves while at the same time promoting other alternatives of development, how people perceive the environment, strengthening community relationships with nature and understanding of environmental conservation. To evaluate the construction area of this project several factors that concern and justify this have been considered. The micro-basin of the Oro River is located outside Bucaramanga and its metropolitan area in the Chimitá valley, where are located industries as food, petrochemicals and car parts. As a result of these industrial and domestic wastes from all metropolitan areas, this river is highly affected, receiving about 1300 liters/sec of wastewater apart from other contaminants [61]. Around the La Loma area, which is surrounded by wastewater, the contamination of Oro River has been associated with the exponential growth in mosquito breeding sites. Mosquitoes transmits hemorrhagic dengue, making the population of that area one of the most affected by the deadly disease; 12 people were reported to have died of the disease in the area in 2008, including eight children [62]. It is projected that CWs will significantly contribute in mitigating the pollution incidence that is primarily responsible for the 
situation. The required work supporting this initiative is described as follows. 1) Development of constructed Wetland System: This aspect of the project will cover around 15 hectares of land. 2) Reforestation. An estimated 500 hectares will be reforested especially on the west side of the Oro River. This is a major remediation work designed to arrest the incidence of ground erosion. 3) Cycle-routes. A system of cycling routes will be integrated into the project area, to be used by tourists and for recreational purposes by local people. These routes will cover several zones of the park, from CW to museums, camping zones, and birds and insects observatories. In total, cycle-routes will cover around $9 \mathrm{~km}$ in length. 4) Park infrastructure. This aspect of the project incorporates the creation of elements of the thematic park as: administrative building, natural museum, birds and insects observatories, restaurants, camping zones, gardens, and other facilities.

All four developments are anticipated to provide the following benefits: Social: cleaner environment, recreational and tourism opportunities, direct and indirect job generation; Environmental: creation of new ecosystems, water treatment, restoration of fishing areas, provide a habitat for several other species, grow expertise in environmental friendly technologies, and control illegal sand exploitation on the river; Economics: restoration of landscape value, provision of income generation opportunities, and low cost of construction and maintenance. On the other hand, a number of problems associated with the project would have to be addressed: Social: displacement of people (around 15 families), and require more space than other systems; Economics: displacement of illegal workers (sand exploitation), the CW systems require extended construction time (30 to 90 days) to stabilize vegetation and level of water.

\section{Conclusion}

Problems associated to pollution in the Oro River Sub-basin include environmental degradation, proliferation of diseases, deterioration of water quality, loss of biodiversity, loss of landscape values, and lack of opportunities for tourism and recreation. This research proposes the use of constructed wetlands systems as an alternative remediation method of the Oro River Sub-basin, providing good water quality and preventing the development of unacceptable pollutant levels. However, a number of factors such as site selection, hydraulic and climatic conditions, hydraulic loading rate and residence time and ability of plant species should be considered in the design and construction of the integrated remediation system. The absence of a comprehensive regional development policy framework is a possible inhibitor to this proposal; hence, actual implementation will require support from all stakeholders. To do this, a systematic and regional approach that allows the best possible allocation of resources is required. In this way, the project will deliver maximum socio-economic and environmental benefits to the entire inhabitants of the Oro River Sub-basin.

\section{Acknowledgements}

This research was supported by the Programme Alban, "the European Union Programme of High Level Scholarships for Latin America", Scholarship No. E05D060429CO, and the Universidad Industrial de Santander for funding C. Ríos during his Ph.D. course at the School of Applied Sciences at the University of Wolverhampton. L. Colmenares thanks to Masunaga Tsugiyuki of the Faculty of Life and Environmental Sciences of Shimane University for his comments and suggestions on the use of CW technology.

\section{References}

[1] Crites, R.W. (1994) Design Criteria and Practice for Constructed Wetlands. Water Science and Technology, 29, 1-6.

[2] Brix, H. (1994) Use of Constructed Wetlands in Water Pollution Control: Historical Development, Present Status, and Future Perspectives. Water Science and Technology, 30, 209-223.

[3] Richardson, C., Qian, S., Craft, C. and Qualls, R. (1996) Predictive Models for Phosphorus Retention in Wetlands. Wetlands Ecology and Management, 4, 159-175. http://dx.doi.org/10.1007/BF01879235

[4] Drizo, A., Frost, C., Smith, K. and Grace, J. (1997) Phosphate and Ammonium Removal by Constructed Wetlands with Horizontal Subsurface Flow, Using Shale as a Substrate. Water Science and Technology, 35, 95-102. http://dx.doi.org/10.1016/S0273-1223(97)00057-7

[5] Peterson, H. (1998) Use of Constructed Wetlands to Process Agricultural Wastewater. Canadian Journal of Plant Science, 78, 199-210. http://dx.doi.org/10.4141/P97-142

[6] Vymazal, J. (2007) Removal of Nutrients in Various Types of Constructed Wetlands. Science of the Total Environment, 
380, 48-65. http://dx.doi.org/10.1016/j.scitotenv.2006.09.014

[7] Hamilton, S.K., Sippel, S.J., Calheiros, D.F. and Melack, J.M. (1997) Ananoxic Event and Other Biogeochemical Effects of the Pantanal Wetland on the Paraguay River. Limnology and Oceanography, 42, 257-272. http://dx.doi.org/10.4319/10.1997.42.2.0257

[8] Chauvelon, P.A. (1998) A Wetland Managed for Agriculture as an Interface between the Rhône River and the Vaccarès Lagoon (Camargue, France): Transfers of Water and Nutrients. Hydrobiologia, 373-374, 181-191. http://dx.doi.org/10.1023/A:1017012531905

[9] Green, M., Safray, I. and Agami, M. (1996) Constructed Wetlands for River Reclamation: Experimental Design, StartUp and Preliminary Results. Bioresource Technology, 55, 157-162. http://dx.doi.org/10.1016/0960-8524(95)00164-6

[10] Jing, S.-R., Lin, Y.-F., Lee, D.-Y. and Wang, T.-W. (2001) Nutrient Removal from Polluted River Water by Using Constructed Wetlands. Bioresource Technology, 76, 131-135. http://dx.doi.org/10.1016/S0960-8524(00)00100-0

[11] He, S.B., Yan, L., Kong, H.N., Liu, Z.M., Wu, D.Y. and Hu, Z.B. (2007) Treatment Efficiencies of Constructed Wetlands for Eutrophic Landscape River Water. Pedosphere, 17, 522-528. http://dx.doi.org/10.1016/S1002-0160(07)60062-9

[12] Zhou, S. and Hosomi, M. (2008) Nitrogen Transformations and Balance in a Constructed Wetland for Nutrient-Polluted River Water Treatment Using Forage Rice in Japan. Ecological Engineering, 32, 147-155. http://dx.doi.org/10.1016/j.ecoleng.2007.10.004

[13] Cooper, P.F., Job, G.D., Green, M.B. and Shutes, R.B.E. (1996) Reed Beds and Constructed Wetlands for Wastewater Treatment. WRc Publications, Buckinghamshire.

[14] Kadlec, R.H. and Knight, R.L. (2003) Treatment Wetlands. CRC Press, Boca Raton, 893 p.

[15] ATTRA-Appropriate Technology Transfer for Rural Areas (2003) Constructed Wetlands. https://attra.ncat.org/attra-pub/summaries/summary.php?pub=319

[16] USEPA - United States Environmental Protection Agency (2004) Constructed Treatment Wetlands, EPA 843-F-03-013. http://www.epa.gov/owow/wetlands/pdf/ConstructedW.pdf

[17] Ghermandi, A. (2005) Evaluating Functions and Benefits of Constructed Wetlands. http:/www.feem-web.it/ess/ess05/files/Ghermandi1.pdf

[18] Ríos, C., Gutiérrez, L. and Aizaki, M. (2007) A Case Study on the Use of Constructed Wetlands for the Treatment of Wastewater as an Alternative for Petroleum Industry. Bistua, 5, 25-41.

[19] Wu, H., Zhang, J., Ngo, H.H., Guo, W., Hub, Z., Liang, S., Fan, J. and Liu, H. (2015) A Review on the Sustainability of Constructed Wetlands for Wastewater Treatment: Design and Operation. Bioresource Technology, 175, 594-601. http://dx.doi.org/10.1016/j.biortech.2014.10.068

[20] Saeed, T. and Sun, G. (2012) A Review on Nitrogen and Organics Removal Mechanisms in Subsurface Flow Constructed Wetlands: Dependency on Environmental Parameters, Operating Conditions and Supporting Media. Journal of Environmental Management, 112, 429-448. http://dx.doi.org/10.1016/j.jenvman.2012.08.011

[21] Calheiros, C.S., Rangel, A.O. and Castro, P.M. (2008) Evaluation of Different Substrates to Support the Growth of Typha latifolia in Constructed Wetlands Treating Tannery Wastewater over Long-Term Operation. Bioresource Technology, 99, 6866-6877. http://dx.doi.org/10.1016/j.biortech.2008.01.043

[22] Ann, Y., Reddy, K.R. and Delfino, J.J. (1999) Influence of Chemical Amendments on Phosphorus Immobilization in Soils from a Constructed Wetland. Ecological Engineering, 14, 157-167. http://dx.doi.org/10.1016/S0925-8574(99)00026-9

[23] Arias, C.A., Del Bubba, M. and Brix, H. (2001) Phosphorus Removal by Sands for Use as Media in Subsurface Flow Constructed Reed Beds. Water Research, 35, 1159-1168. http://dx.doi.org/10.1016/S0043-1354(00)00368-7

[24] Xu, D., Xu, J., Wu, J. and Muhammad, A. (2006) Studies on the Phosphorus Sorption Capacity of Substrates Used in Constructed Wetland Systems. Chemosphere, 63, 344-352. http://dx.doi.org/10.1016/j.chemosphere.2005.08.036

[25] Tao, W. and Wang, J. (2009) Effects of Vegetation, Limestone and Aeration on Nitritation, Anammox and Denitrification in Wetland Treatment Systems. Ecological Engineering, 35, 836-842. http://dx.doi.org/10.1016/j.ecoleng.2008.12.003

[26] Seo, D.C., Cho, J.S., Lee, H.J. and Heo, J.S. (2005) Phosphorus Retention Capacity of Filter Media for Estimating the Longevity of Constructed Wetland. Water Research, 39, 2445-2457. http://dx.doi.org/10.1016/j.watres.2005.04.032

[27] Brooks, A.S., Rozenwald, M.N., Geohring, L.D., Lion, L.W. and Steenhuis, T.S. (2000) Phosphorus Removal by Wollastonite: A Constructed Wetland Substrate. Ecological Engineering, 15, 121-132. http://dx.doi.org/10.1016/S0925-8574(99)00056-7

[28] Bruch, I., Fritsche, J., Bänninger, D., Alewella, U., Sendelov, M., Hürlimann, H., Hasselbach, R. and Alewell, C. (2011) 
Improving the Treatment Efficiency of Constructed Wetlands with Zeolite-Containing Filter Sands. Bioresource Technology, 102, 937-941. http://dx.doi.org/10.1016/j.biortech.2010.09.041

[29] Cui, L., Ouyang, Y., Lou, Q., Yang, F., Chen, Y., Zhu, W. and Luo, S. (2010) Removal of Nutrients from Wastewater with Canna indica L. under Different Vertical-Flow Constructed Wetland Conditions. Ecological Engineering, 36, 1083-1088. http://dx.doi.org/10.1016/j.ecoleng.2010.04.026

[30] Ren, Y., Zhang, B., Liu, Z. and Wang, J. (2007) Optimization of Four Kinds of Constructed Wetlands Substrate Combination Treating Domestic Sewage. Wuhan University Journal of Natural Sciences, 12, 1136-1142. http://dx.doi.org/10.1007/s11859-007-0085-X

[31] Babatunde, A.O., Zhao, Y.Q. and Zhao, X.H. (2010) Alum Sludge-Based Constructed Wetland System for Enhanced Removal of P and OM from Wastewater: Concept, Design and Performance Analysis. Bioresource Technology, 101, 6576-6579. http://dx.doi.org/10.1016/j.biortech.2010.03.066

[32] Mateus, D.M.R., Vaz, M.M.N. and Pinho, H.J.O. (2012) Fragmented Limestone Wastes as a Constructed Wetland Substrate for Phosphorus Removal. Ecological Engineering, 41, 65-69. http://dx.doi.org/10.1016/j.ecoleng.2012.01.014

[33] Hill, D.T., Payne, V.W.E., Rogers, J.W. and Kown, S.R. (1997) Ammonia Effects on the Biomass Production of Five Constructed Wetland Plant Species. Bioresource Technology, 62, 109-113. http://dx.doi.org/10.1016/S0960-8524(97)00085-0

[34] Chong, H.L., Chia, P.S. and Ahmad, M.N. (2013) The Adsorption of Heavy Metal by Bornean Oil Palm Shell and Its Potential Application as Constructed Wetland Media. Bioresource Technology, 130, 181-186. http://dx.doi.org/10.1016/j.biortech.2012.11.136

[35] Singh, S.P. (1998) Chronic Disturbance, a Principal Cause of Environmental Degradation in Developing Countries. Environmental Conservation, 25, 1-2. http://dx.doi.org/10.1017/S0376892998000010

[36] UNRISD - United Nations Research Institute for Social Development (1994) Environmental Degradation and Social Integration. Briefing Paper No. 3, World Summit for Social Development. http://www.unrisd.org/unrisd/website/document.nsf/ab82a6805797760f80256b4f005da1ab/52b8b9ca2197847380256b 65004c9cc9/\$FILE/bp3.pdf

[37] El Araby, M. (2002) Urban Growth and Environmental Degradation: The Case of Cairo, Egypt. Cities, 19, $389-400$. http://dx.doi.org/10.1016/S0264-2751(02)00069-0

[38] Diao, X.D., Zeng, S.X., Tam, C.M. and Tam, V.W.Y. (2009) EKC Analysis for Studying Economic Growth and Environmental Quality: A Case Study in China. Journal of Cleaner Production, 17, 541-548. http://dx.doi.org/10.1016/j.jclepro.2008.09.007

[39] United Nations (2005) The International Decade for Action: "Water for Life" 2005-2015. http://www.un.org/waterforlifedecade/pdf/waterforlifebklt-e.pdf

[40] Rahman, M., Hassan, M.Q., Islam, M.S. and Shamsad, S.Z.K.M. (2000) Environmental Impact Assessment on Water Quality Deterioration Caused by the Decreased Ganges Outflow and Saline Water Intrusion in Southwestern Bangladesh. Environmental Geology, 40, 31-40. http://dx.doi.org/10.1007/s002540000152

[41] Smolders, R., Bervoets, L. and Blust, R. (2004) In Situ and Laboratory Bioassays to Evaluate the Impact of Effluent Discharges on Receiving Aquatic Ecosystems. Environmental Pollution, 132, 231-243. http://dx.doi.org/10.1016/i.envpol.2004.04.019

[42] Dietz, S. and Adger, W.N. (2003) Economic Growth, Biodiversity Loss and Conservation Effort. Journal of Environmental Management, 68, 23-35. http://dx.doi.org/10.1016/S0301-4797(02)00231-1

[43] SCBNAS - Society of Conservation Biology, North America Section (2004) The Steady State Economy as a Sustainable Alternative to Economic Growth. SCB, Arlington, Virginia. http://conbio.org/groups/working-groups/social-science/resources/symposia

[44] Antrop, M. (2005) Why Landscapes of the Past Are Important for the Future. Landscape and Urban Planning, 70, 21-34. http://dx.doi.org/10.1016/j.landurbplan.2003.10.002

[45] Kim, K.H. and Pauleit, S. (2007) Landscape Character, Biodiversity and Land Use Planning: The Case of Kwangju City Region, South Korea. Land Use Policy, 24, 264-274. http://dx.doi.org/10.1016/j.landusepol.2005.12.001

[46] Ezeah, C. and Roberts, C.L. (2013) Waste Governance Agenda in Nigerian Cities: A Comparative Analysis. Habitat International, 41, 121-128.

[47] IASON-International Action for the Sustainability of the Mediterranean and Black Sea Environment (2007) An Assessment of the Projected Socio-Economic Impact of the Various Hazards and Threats on the Stability/Sustainability of the System. 6th Framework Programme No. 515234. http://www.iasonnet.gr/library/final_deliverables/IASON_515234_D5-2.pdf 
[48] Mitsch, W.J. and Gosselink, J.G. (2000) The Value of Wetlands: Importance of Scale and Landscape Setting. Ecological Economics, 35, 25-33. http://dx.doi.org/10.1016/S0921-8009(00)00165-8

[49] O‘Neill, M., Loomis, D., Borja, V., Gold, D., Hertz, I. and Castillejos, M. (2004) Do Associations between Airborne Particles and Daily Mortality in Mexico City Differ by Measurement Method Region, or Modeling Strategy. Journal of Exposure Analysis and Environmental Epidemiology, 14, 429-439. http://dx.doi.org/10.1038/sj.jea.7500341

[50] Seaton, A., MacNee, W., Donaldson, K. and Godden, D. (1995) Particulate Air Pollution and Acute Health Effects. Lancet, 345, 176-178. http://dx.doi.org/10.1016/S0140-6736(95)90173-6

[51] Kelleher, P., Pacheco, K. and Newman, L. (2000) Inorganic Dust Pneumonias: The Metal Related Parenchymal Disorders. Environmental Health Perspectives, 108, 685-696. http://dx.doi.org/10.1289/ehp.00108s4685

[52] Dockery, D.W. and Stone, P.H. (2007) Cardiovascular Risks from Fine Particulate Air Pollution. The New England Journal of Medicine, 356, 511-513. http://dx.doi.org/10.1056/NEJMe068274

[53] Kaiser, J. (2003) Manganese: A High Octane Dispute. Science, 300, 926-928. http://dx.doi.org/10.1126/science.300.5621.926

[54] Tullock, J. and Richards, L. (1993) Childhood Diarrhoea and Acute Respiratory Infections in Developing Countries. The Medical Journal of Australia, 159, 46-51.

[55] Cholera Working Group (1993) Large Epidemic of Cholera-Like Disease in Bangladesh Caused by Vibrio cholerae O139 Synonym Bengal. Lancet, 342, 387-390. http://dx.doi.org/10.1016/0140-6736(93)92811-7

[56] Turvill, J., Wapnir, R., Wingertzahn, M., Teichberg, S. and Farthing, M. (2000) Cholera Toxin-Induced Secretion in Rats Is Reduced by a Soluble Fiber, Gum Arabic. Digestive Diseases and Sciences, 45, 946-951. http://dx.doi.org/10.1023/A:1005529209427

[57] Ezeah, C., Fazakerley, J.A. and Byrne, T. (2015) Tourism Waste Management in the European Union: Lessons Learned from Four Popular EU Tourists Destinations. Sage Open Access Journal. (In Print)

[58] Mohammed, S.M. (2002) Pollution Management in Zanzibar: The Need for a New Approach. Ocean \& Coastal Management, 45, 301-311. http://dx.doi.org/10.1016/S0964-5691(02)00060-1

[59] Ehrenfeld, J.G. (2000) Evaluating Wetlands within an Urban Context. Ecological Engineering, 15, $253-265$. http://dx.doi.org/10.1016/S0925-8574(00)00080-X

[60] Burger, J. (2000) Landscapes, Tourism, and Conservation. Science of the Total Environment, 249, 39-49. http://dx.doi.org/10.1016/S0048-9697(99)00509-4

[61] Gutiérrez, J.C. (2006) En las entrañas del Río de Oro, Premio de Reportaje sobre Biodiversidad. http://www.biodiversityreporting.org/article.sub?docId=23499\&c=Colombia\&cRef=Colombia\&year=2007\&date=May $\underline{0202006}$

[62] Vanguardía Liberal (2009) El Río de Oro es una alcantarilla. http://www.vanguardia.com/santander/bucaramanga/18726-el-rio-de-oro-es-una-alcantarill 